\title{
The Effect of Repeat Tax Amnesty and Tax Penalty Policy on Taxpayer Compliance (An Experimental Study)
}

\author{
Ni Putu Riasning ${ }^{1}$, Anak Agung Bagus Amlayasa ${ }^{2}$, Luh Kade Datrini ${ }^{3}$ \\ 1,2,3 Department of Accounting, Faculty of Economic and Busines, \\ Warmadewa University, Denpasar-Bali, Indonesiaa \\ Corresponding Author: Anak Agung Bagus Amlayasa
}

\begin{abstract}
This study aims to (1) examine the effect of repeated tax amnesty knowledge on taxpayer compliance, (2) examine the effect of tax sanctions on taxpayer compliance based on threats to taxpayer compliance decisions, and (3) examine differences in taxpayer compliance based on taxpayer knowledge, on the reimplementation of tax amnesty and the effect of tax sanctions on taxpayer compliance decisions. This study used a $2 \times 2$ factorial experimental research design between subjects by using 119 participants from accounting students from the Faculty Economic and Busines Warmadewa University. The results showed that both the knowledge of taxpayers on the reimplementation of tax amnesty and the effect of tax sanctions on taxpayer compliance decisions can affect taxpayer compliance. Besides that too, there is an interaction between taxpayer knowledge on the re-implementation of tax amnesty and the effect of tax sanctions on taxpayer compliance decisions where if the taxpayer is in a condition not aware of the repeated application of the tax amnesty, taxpayers who also receive high tax sanctions will show the highest degree of compliance, compared to subjects in other situations. Hypothesis testing using a different test $t$ test with the help of the SPSS 26.0 program. The expected research output is that the results of this research will be published in the proceedings of the Warmadewa of University Research Institute
\end{abstract}

Keywords: Recurring tax forgiveness, tax sanctions, tax compliance

\section{INTRODUCTION}

One way for the government to increase revenue from the tax sector is to implement a tax amnesty policy strategy. Tax forgiveness is a policy that erases the past of taxpayers who did not comply and violated the rules (Ngadiman and Huslin, 2015). On July 1, 2016, the Indonesian government finally ratified the rules regarding tax amnesty as regulated in the Law of the Republic of Indonesia Number 11 of 2016 concerning Tax Amnesty. According to Alm (1998) the tax amnesty policy has the potential to encourage voluntary tax compliance in the future after the tax amnesty is carried out. This policy is still new in Indonesia, making it an interesting phenomenon to study.

Tax amnesty policies have been implemented in many countries around the world. Some countries have succeeded in implementing this policy, but many countries have failed. Successful countries such as Ireland, South Africa, and Italy implemented a tax amnesty policy accompanied by strict law enforcement efforts, while the failure of several countries was due to too often the policy was applied in these countries such as India (11 times), Bangladesh (18 times), and Sri Lanka (11 times) (Ibrahim et al., 2017). Indonesia itself has carried out this policy twice, in 1964 and 1984, which were deemed to have failed because taxpayers did not respond and were not followed by a comprehensive 
reform of the tax administration system (Ragimun 2015). However, in the midst of the Covid-19 pandemic that is engulfing the world and also Indonesia, there are rumors that the government has a discourse to provide tax amnesty volume II as has been reported by several mass media, both print, electronic and online media.

Although this policy is expected to increase tax compliance, empirical research results found different or contradictory results. Several studies on tax amnesty and taxpayer compliance were conducted using survey methods. Sari and Ayu (2017) find that there is a positive effect of tax amnesty and tax knowledge on compliance. This study uses a survey method and was conducted in the Surabaya Tegalsari area. This finding was confirmed by Puspareni et al. (2017) which reveal that partially and simultaneously tax amnesty, economic growth, taxpayer compliance, and institutional transformation of the Directorate General of Taxes have a positive and significant effect on tax revenue.

However, several other studies yielded different findings. Gerger (2012) conducted a survey of 240 respondents in Turkey and found the fact that the average taxpayer compliance has decreased due to tax amnesty. The reason, among others, is the results of the Turkish government often perform tax amnesty. Research conducted by López-Laborda and Rodrigo (2003) found that the implementation of tax amnesty in Spain had no effect on tax revenues. This study uses a time-series analysis with data from 1979 to 1998 . Alm, McKee, and Beck (1990) using an experimental approach in "Amazing Grace: Tax Amnesties and Compliance" stated that the average level of compliance decreased after tax amnesty. According to him, the tax amnesty will succeed in increasing compliance if post-amnesty enforcement is carried out after the tax amnesty. They further said that tax amnesty would be an effective tool as a means of transition to a more assertive tax regime. In order for the tax amnesty policy to be effective, its implementation must be done only once, because repeated tax amnesty has the effect of reducing revenue receipts and compliance levels. The United States state tax amnesty and other international amnesty experiences indicate that repeated amnesties will result in slower amounts of revenue (Ahmed 2016).

Some of the studies above show the fact that the relationship between tax amnesty and tax compliance has not yet produced an agreement. Some say there is a positive relationship, but some say the opposite. Based on the things above, it is necessary to do further research to find out how the relationship between tax amnesty and taxpayer compliance is deeper. However, the limited phenomenon of this recurring tax amnesty policy behind the government's intention to increase taxpayer compliance can be mitigated by the application of strict tax sanctions. Like Ali, Cecil, and Knoblett (2001), tax sanctions are a very effective policy to prevent taxpayer non-compliance because tax sanctions will make taxpayers more obedient and provide a deterrent effect to taxpayers who violate or do not comply with tax regulations that apply.

Tax sanctions imposed on unreported income by taxpayers will affect tax compliance (Allingham and Sandmo 1972). The higher sanctions imposed on taxpayers will encourage taxpayers to comply (Santoso 2008). Tax sanctions imposed on violators can be in the form of administrative sanctions or criminal sanctions (Pranata and Setiawan 2015). According to Hutagaol, Winarko, and Pradipta (2007) the application of tax sanctions, both administrative (fines, interest and increases) and criminal (imprisonment or imprisonment) encourages taxpayer compliance but the application of tax sanctions must be consistent and applies to all taxpayers who do not meet tax obligations due to discriminatory and unfair tax treatment resulting in low tax compliance. 
Several studies also prove that a higher level of sanctions will have an impact on higher compliance (Lederman 2003). Research conducted by Muliari and Setiawan (2011) found that tax sanctions have a positive effect on taxpayer reporting compliance. In addition, research conducted by Allingham and Sandmo (1972), Alm, Jackson, and Mckee (1992), Ali et al., (2001), Hutagaol et al., (2007), Cahyonowati, Ratmono, and Faisal (2012), Ngadiman and Huslin (2015) explains that tax sanctions have an effect on increasing taxpayer compliance.

Based on the phenomena and previous empirical studies, it has been found that there are research gaps to be researched and re-analyzed. The gaps in this research can be described as follows: (1) The phenomenon of recurring tax amnesty is still a new issue. This is an opportunity for researchers to see how the level of response or participation from taxpayers regarding the policies that have been given, $\{2\}$ Almost most of the empirical studies, using the survey method. However, the validity of these findings has not been confirmed because in the survey there is a social desirability bias in which respondents will try to give good answers socially and this research is still limited by using an experimental design. This adds an opportunity for researchers to develop further by using experimental settings where biases in survey research will be reduced. Therefore, the use of this experimental method is intended to obtain the novelty value of this study compared to previous research.

\section{LITERATURE REVIEW Slippery Slope Theory}

Slippery slope theory is one of the theories that have recently been used to explain the behavior of taxpayers. Slippery slope theory views that there are two important variables that affect taxpayer compliance in fulfilling their tax payment obligations, namely the taxpayer's trust in the tax authority (trust) and the authority's strength in carrying out the taxation process (power) (Kirchler et al., 2008). Taxpayers will feel confident in the tax authorities if the tax authorities are very transparent and accountable in carrying out the taxation process (Wahl et al., 2010). In addition, taxpayers will view that the tax authority has power if the tax authority has a firm system in the taxation process, such as a system of inspection and punishment for non-compliant taxpayers in paying taxes (Prinz et al., 2014). These two variables (trust and power) will shape taxpayer compliance, either voluntary or forced compliance.

A transparent, accountable and responsible tax administration system will foster taxpayer confidence in the tax authorities. This raises awareness of taxpayers to pay taxes voluntarily. In addition to trust, the power of the tax authority can affect taxpayer compliance, but this compliance is forced. Based on the research of Faizal et al., (2017), Kastlunger et al., (2013), Kirchler et al., (2008) the power of tax authorities in supervising the taxation process can improve taxpayer compliance even though the tax authorities do not carry out the taxation process in a transparent, accountable and responsible manner answer. This is based on the ability of the tax authorities in supervising and punishing tax evaders, thereby creating fear in taxpayers if they do not pay taxes.

From the explanation above, it can be seen that the taxpayer's trust in the tax authority plays an important role in encouraging taxpayers to comply voluntarily. Meanwhile, the power of the authorities in carrying out the taxation process tends to encourage taxpayers to comply compulsorily. These two elements together can influence the behavior of taxpayers. Voluntary compliance of taxpayers will be high if the taxpayer has high trust in the tax authorities, without being influenced by the ability of the tax authorities to carry out the taxation process (power) (Faizal et al., 2017). Although the tax authorities do not have the ability to 
monitor the taxation process optimally, the taxpayer's trust in the tax authorities will raise awareness to pay taxes voluntarily. On the other hand, taxpayer voluntary compliance will be low if the taxpayer feels distrustful of the tax administration by the tax authorities. This can be exacerbated if the tax authorities do not have the ability to monitor the taxation process optimally, so that taxpayers tend to avoid paying taxes. However, if the tax authorities have the ability to supervise the taxation process and have a strict punishment system for tax evaders, then this will encourage taxpayers to comply with paying taxes, but compliance is forced (Faizal et al., 2017, Kastlunger). et al., 2013, Kirchler et al., 2008).

\section{Tax payer Compliance}

According to Ardiyanti and Supadmi (2020) tax compliance is a condition where the taxpayer fulfills all tax obligations and exercises tax rights. Solih et al. (2020), put forward a widely accepted principle of tax administration stating that the goal to be achieved is voluntary compliance. Voluntary compliance is the backbone of the self-assessment system in which taxpayers are responsible for determining their own tax obligations and then paying and reporting the tax in an accurate and timely manner.
There are two basic perspectives of compliance with the law, namely instrumental and normative. Instrumental perspective means individuals with selfinterest and responses to behavioral changes. The normative perspective relates to morals and is opposed to self-interest. A person is more likely to obey the law that is considered appropriate and consistent with their norms. Normative commitment through personal morality means obeying the law because the law is considered a necessity, while normative commitment through legitimacy means obeying the rules because the law-making authority has the right to dictate behavior (Saleh, 2004).

According to Nurmantu (2005), it is explained that there are two kinds of compliance, the first is formal compliance. Formal compliance is a condition where the taxpayer fulfills his tax obligations formally in accordance with the provisions of the Taxation Law. In this case, formal compliance includes taxpayers paying taxes on time, taxpayers paying taxes in the right amount, taxpayers not having land and building tax dependents. And the second is material compliance. Material compliance is a condition where the taxpayer substantially or essentially fulfills all tax provisions, namely in accordance with the content and spirit of the tax law.

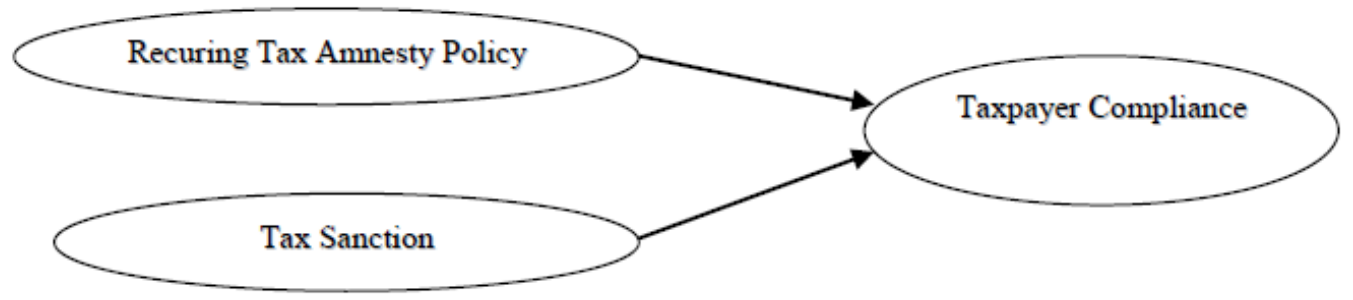

Figure.1 Research concept framework

\section{The Effect of Recurring Tax Amnesty Policy on Tax Compliance}

The tax amnesty policy is widely applied by countries in the world within the framework of the country's fiscal policy in order to maximize tax potential that has not been explored properly. Generally, the background of a country implementing this policy is because of the rise of underground economy activities. Underground economy activities are legal or illegal activities that are missed from the calculation of Gross Domestic Product (GDP), so that from a tax perspective this activity can eliminate potential taxes that should be obtained. According to Schneider and Enste (2002), 
the level of the underground economy in developed countries can reach $14-16 \%$, while in developing countries it reaches $35-$ $44 \%$. In addition, it is known that a large amount of capital has been transferred abroad

According to Herman et al, (2019), tax compliance will increase through individual perceptions of a fair tax system. When the government is able to create a fair taxation system, especially in the framework of the tax amnesty policy, short-term and long-term success can be achieved. Kartini (2018) also states that tax evasion can be overcome by the existence of fines and inspections. For this reason, the government needs to pay attention to the behavior of the community in making the tax amnesty policy framework in order to achieve shortterm and long-term success. This is also emphasized by Kartini (2018) that the tax amnesty policy can be a very useful tool when a country moves from the old tax system to a new, better system.

The emergence of the phenomenon of tax amnesty that is carried out repeatedly makes taxpayers who do not know about the existence of repeated tax amnesty will have a high obedient attitude because they are afraid of being subject to fines and sanctions if they fail to pay taxes, while taxpayers who are aware of the existence of repeated tax amnesty will have a negative attitude. disobedient, because they will disclose their unreported assets when the tax amnesty is implemented in order to avoid fines and sanctions for failing to report their assets. This of course will make obedient taxpayers feel this policy is unfair, because when they pay their obligations obediently, Taxpayers who do not comply are given relief to pay the amount of money charged without being subject to fines or sanctions due to late disclosure (Rechberger, et al. 2010). The introduction of a tax amnesty may also affect social compliance norms. Tax amnesty can reduce compliance if honest taxpayers resent the tax amnesty granted to tax fraud (and if people believe amnesty can be repeated) (Alm 1998). The sense of justice felt by taxpayers towards the taxation system is an important factor in determining the compliance behavior of taxpayers to fulfill their tax obligations. So the first hypothesis proposed is: Tax amnesty can reduce compliance if honest taxpayers resent the tax amnesty granted to tax fraud (and if people believe amnesty can be repeated) (Alm 1998). The sense of justice felt by taxpayers towards the taxation system is an important factor in determining the compliance behavior of taxpayers to fulfill their tax obligations. So the first hypothesis proposed is: Tax amnesty can reduce compliance if honest taxpayers resent the tax amnesty granted to tax fraud (and if people believe amnesty can be repeated) (Alm 1998). The sense of justice felt by taxpayers towards the taxation system is an important factor in determining the compliance behavior of taxpayers to fulfill their tax obligations.

H1: Taxpayers who are not aware of the implementation of repeated tax amnesty will have high tax compliance

The effect of tax sanctions on taxpayer compliance.

Mardiasmo (2016) states that tax sanctions are a guarantee that the provisions of tax laws (tax norms) will be complied with/obeyed/obeyed, in other words, tax sanctions are a deterrent so that taxpayers do not violate tax norms. The tax collection system in Indonesia is using a selfassessment system, where this system is a tax collection system that gives authority, trust, and responsibility to taxpayers to calculate, pay and report themselves the amount of tax to be paid. To regulate the actions of the taxpayer, tax sanctions are needed as signs regulated in the applicable tax laws so that tax collection can run in an orderly manner and in accordance with the expected target. If a tax obligation is not carried out by the taxpayer, there will be legal consequences that must be imposed on the taxpayer. The legal consequence is the imposition of tax sanctions where according to Law Number 28 of 2007 concerning General Provisions and Tax Procedures, 
there are 2 types of sanctions, namely administrative sanctions (fines, interest and increases) and criminal sanctions (imprisonment and imprisonment).

Tax sanctions are a policy of the Directorate General of Taxes to improve taxpayer compliance. Allingham and Sandmo (1972) explain that tax sanctions imposed on income that are not reported by taxpayers will affect tax compliance. The higher the sanctions imposed on taxpayers will encourage taxpayers to comply (Santoso, 2008). Taxpayers' perceptions of tax sanctions will greatly affect taxpayer compliance because taxpayers will feel burdened if they do not comply with tax laws, the remaining arrears that have not been paid by taxpayers must be repaid immediately plus the fines that must be received. Muliari and Setiawan (2011), Cahyonowati et al., (2012) and Hantoyo et al., (2016) stated that tax sanctions or tax penalties have a positive and significant effect on tax compliance. Therefore, tax sanctions are expected to affect the level of tax compliance. This is supported by research

H2: High tax sanctions will reduce the tendency of individual taxpayers to take tax non-compliance actions compared to low tax sanctions

The Effect of Recurring Tax Amnesty Policy and Tax Sanctions Together on Tax Non-compliance

Tax amnesty can reduce compliance if honest taxpayers hate the tax amnesty granted to tax fraudsters (and if people believe that amnesty can be repeated) (Alm, 1998). With tax sanctions, taxpayers will be motivated to always comply with taxes. This is because if the Taxpayer is not obedient in paying or calculating the tax, it will be given a penalty (punishment) in the form of administrative or criminal sanctions that will provide a deterrent effect to the Taxpayer. Tax sanctions and tax amnesty policies are contradictory policies. However, these two policies will work if they support each other. This is supported by research conducted by Ngadiman and
Huslin (2015) that tax sanctions and tax amnesty have a positive and significant effect on tax compliance. Research Alm et al., (1990) explains that tax amnesty can improve tax compliance in the future if accompanied by strong enforcement and penalties for violators or tax evaders. This means that the tax amnesty policy must be implemented if it is followed by stronger law enforcement and improving tax administration

H3: Taxpayers who are aware of the existence of repeated tax amnesty and feel the existence of high tax sanctions can reduce the tendency of individual taxpayers to take tax non-compliance

\section{MATERIALS \& METHODS Research design}

The research design used in this research is an experimental method, because the experimental method examines the relationship between the dependent variable and the independent variable, has high internal validity by controlling for other variables that have the potential to disrupt the relationship. The experimental research design was a $2 \times 2$ factorial design between subjects. The first factor is knowledge oftax amnesty which consists of two levels, namely: the taxpayer is aware of the existence of tax amnesty recurring and taxpayers who are not aware of the existence of tax amnesty repeated. Furthermore, the second factor is tax sanctions. This second factor consists of two levels, namely mandatory sanctions at a high level and tax sanctions at a low level.

Table 1: Experiment Matrix
\begin{tabular}{|l|c|c|}
\hline \multicolumn{1}{|c|}{ Variable } & Tax Sanction \\
\hline Knowledge of Recurring Tax Amnesty & High & Low \\
\hline Know & Cell 1 & Cell 2 \\
\hline Do not know & Cell 3 & Cell 4 \\
\hline
\end{tabular}

\section{Information:}

Cell 1: Knowing the existence of recurring tax amnesty and the implementation of high tax penalties

Cell 2: Knowing the existence of recurring tax amnesty and the application of low sanctions 
Cell 3: Not aware of recurring tax amnesty and implementation of high tax penalties

Cell 4: Not aware of recurring tax exemptions and the application of low tax penalties.

\section{Experiment Participants}

The experimental participants in this study were undergraduate students majoring in accounting who had passed the taxation course at the Accounting Department, Faculty of Economics and Business, Warmadewa University. The reason for selecting student participants who will be used as a substitute for individual taxpayers who carry out business activities is because the researchers do not intend to generalize the results of the study but rather to test theories that explain causality. In addition, the dependent variable in this study is general judgment so that when using participants in the form of real taxpayers, the variable in the form of experience is feared to interfere with the results of the study.

\section{Check Manipulation}

In this study, manipulation checks were carried out by giving 3 questions to participants in the form of statements. Participants were asked to choose one of the questions that best described the conditions they experienced in the case material. The four manipulation questions are related to the role and conditions of the tax amnesty policy.

\section{Data analysis technique}

Presenting descriptive statistical analysis obtained from research subject data, 2) Conduct a randomization effectiveness test using one-way ANOVA with the dependent variable being the level of compliance and the independent variables: gender, age, and student achievement index. 3) Perform manipulation checks. Manipulation checking is done by determining the score of the subject's answers to the questions given, if the subject answers the two questions in the presentation test section correctly, the subject is declared to have passed the manipulation check. 4) Testing the hypothesis by means of an independent t-test for the first and second hypotheses, and two-way ANOVA with the help of SPSS 26 software for the third hypothesis.

\section{RESULT}

\section{Characteristics of Respondents}

Participants in this study consisted of 119 students who were divided into 4 cells. Table 4 shows that the number of participants for all cells is almost the same. Through the table, it can also be seen the results of the manipulation checks carried out through an understanding test of the roles and situations faced by the research subjects. Subjects passed the manipulation if they could answer at least two of the three questions presented correctly. Thus, 100\% of the subjects in each cell that followed the experiment were declared to have passed the manipulation.

In experimental research, the first thing that needs to be ascertained is the effectiveness of the randomization. Therefore, to ensure the effectiveness of randomization, further statistical testing is needed. A randomization is considered effective if there is no influence of demographic characteristics on the dependent variable. The dependent variable in this study is taxpayer compliance. Statistical testing to see the results was carried out with One Way ANOVA and the test results are presented in table 5 below.

Table 2: Results of Randomization of Demographic
Characteristics
\begin{tabular}{|l|c|c|}
\hline Independent Variable & Taxpayer Compliance \\
\cline { 2 - 3 } & F-Stats & Sig \\
\hline Age & 0.225 & 0.951 \\
\hline Gender & 0.047 & 0.828 \\
\hline grade-point average & 0.182 & 0.834 \\
\hline
\end{tabular}

Based on the results of the One-way ANOVA test in table 5, it is known that there is no influence of demographic characteristics in terms of age, gender and cumulative achievement index on taxpayer compliance. This can be seen from the 

experimental study)

significance level of all demographic characteristic variables which are above 0.05. Thus, it can be concluded that the results of research between research cells will really be due to the manipulation given to each cell and not the result of differences in the demographic characteristics of research subjects. In other words, the variables that have the potential to interfere with the relationship between the independent variable (knowledge of repeated tax amnesty and the effect of social norms on taxpayers) and the dependent variable (tax compliance) can be controlled. Further manipulation testing needs to be done to ensure that the participants have received the manipulation well. Through independent sample t-test, it can be seen the success of the manipulation of taxpayer knowledge regarding the possibility of tax amnesty in the future period and the effect of tax sanctions on taxpayer compliance decisions. Knowledge scores of recurring tax amnesty from cells 1 and 2 (knowing there is tax amnesty) will be compared with cells 3 and 4 (don't know there is tax amnesty), while the score of the effect of tax sanctions on taxpayer compliance from cells 1 and 3 (the effect of high tax sanctions) compared to cells 2 and 4 (low tax penalty effect). The statistical results of the manipulation test are shown in table 3 below.

\begin{tabular}{|c|c|c|c|}
\hline Variable & Average & & Sig \\
\hline \multirow[t]{2}{*}{ Knowledge of the Possibility of Recurring tax amnesty } & Know & 74.23 & \multirow[t]{2}{*}{$0.000 *$} \\
\hline & Do not know & 46,16 & \\
\hline \multirow[t]{2}{*}{ Tax Sanction } & High & 81.89 & \multirow[t]{2}{*}{$0.000 *$} \\
\hline & Low & 56.06 & \\
\hline
\end{tabular}

Table 3 shows the difference in scores between experimental groups based on knowledge of the possibility of tax amnesty in the future period and the effect of tax sanctions on compliance decisions. The score of the group who knew there was tax amnesty in the future period was significantly different compared to the score of the participants in the group who did not know there was tax amnesty (sig $0.000<$ 0.05). Likewise, the score of the high tax sanction group was significantly different from the score of the low tax sanction group at a significance level of $5 \%$. The group that knows the re-implementation of tax amnesty has a higher average compliance score than the group who does not know, as well as the high tax sanctions group has a higher average compliance score than the opposite group.

\section{Data Analysis}

The main effect in this experimental study can be seen from the knowledge of the possibility of tax amnesty ( $\mathrm{H} 1$ and $\mathrm{H} 2$ ). Differences in knowledge compliance with the application of tax amnesty can be seen by comparing the compliance scores who know there4is tax amnesty (cell 1 and cell 2) with those who do not know there is a recurring tax amnesty (cell 3 and cell 4).

Table 4: Hypothesis Testing Results

\begin{tabular}{|c|l|l|c|c|}
\hline Hypothes & \multicolumn{1}{|c|}{ Variable } & Average Compliance Rate & Sig \\
\hline 1 & Knowledge of Recurring Tax Amnesty & Tofu & $56.000^{*}$ \\
\cline { 3 - 5 } & & Do not know & 70.91 \\
\hline 2 & Effect of Tax Penalties & High & 70,20 \\
\cline { 3 - 5 } & & Low & 57.39 \\
\hline 3 & Knowledge Interaction of Recurring Tax & Know-High Sanctions & 61.72 \\
\cline { 3 - 5 } & Forgiveness and Tax Sanctions & Know-Low Sanctions & 50.93 \\
\cline { 3 - 5 } & & Don't Know-High Sanctions & 78.68 \\
\cline { 3 - 5 } & & Don't Know-Low Sanctions & 63.64 \\
\end{tabular}

Note: * significant at $5 \%$ 
Meanwhile, in order to determine the main effect of the effect of tax sanctions, a comparison of the compliance scores of taxpayers who have high tax sanctions (cells 1 and 3) with those with low tax sanctions is carried out (cells 2 and 4). The second hypothesis states that high tax penalties will result in a high level of compliance in fulfilling their tax obligations. The test results using the independent sample t-test in table 7 show that the average compliance score of taxpayers who have high tax sanctions is 70.20 which is higher than the average compliance score of taxpayers who have low tax sanctions, which is only 57. 39 . With a significance value of 0.001 , it means that the second hypothesis can be accepted at a significance of $=5 \%$.

Based on the test results above, it can also be seen the results of the interaction between the knowledge variable on recurring tax amnesty and tax sanctions on taxpayer compliance. In the condition of taxpayers who do not know of the application of repeated tax amnesty, taxpayers who receive high tax sanctions are expected to have the highest compliance when compared to other groups of taxpayers. The average compliance score for taxpayers who do not know about the application of recurring tax amnesty and taxpayers who have high tax sanctions produces the highest score of 78.68, while taxpayers who know about the existence of recurring tax amnesty and taxpayers who receive tax sanctions low score has the lowest compliance score of 50.93. Through interaction testing using a two-way ANOVA, a significance level of 0.000 was obtained so that the third hypothesis in this study was accepted at a significance level of $=5 \%$. The average taxpayer compliance score in cell 3 (does not know there is a recurring tax amnesty and receives high tax sanctions) is the highest compared to other cells

\section{DISCUSSION}

Based on the results of testing the first hypothesis, it is known that taxpayers who do not know the implementation of repeated tax amnesty have a high obedient attitude towards taxes. This is in line with research (Alm 1998) which says that tax amnesty can reduce compliance if honest taxpayers hate the tax amnesty granted to tax fraud (and if people believe that amnesty can be repeated). Although several studies have proven that the existence of tax amnesty will have implications for increasing taxpayer compliance (Ngadiman and Huslin, 2015; Puspareni, Purnamawati and Wahyuni, 2017) but if the application of tax amnesty is repeated, it will lead to noncompliance. A one-time tax amnesty and supported by a more stringent sanctions mechanism can facilitate willingness to pay taxes. Gerger (2012) argues that amnesty reduces post-amnesty tax compliance, because the introduction of amnesties increases taxpayers' expectations of repeated amnesties. The most important reason against the amnesty of recurring taxes is that it is against the principle of justice.

When government authorities discuss the introduction of a tax amnesty, they should particularly emphasize that it is not their goal to let people escape without proper sanctions. Instead, they must communicate that taxpayers who use the tax amnesty facility must pay some of their debts and demonstrate a willingness to pay all their taxes honestly in the future. Through the tax amnesty people who previously evaded taxes are given the opportunity to return to compliance, which ultimately benefits all taxpayers (Rechberger, et al. 2010).

The results also support the second hypothesis, indicating that taxpayers who receive high tax sanctions will encourage taxpayers to be obedient. This is in line with the results of Hidayat and Nugroho's research (2010) which says that the effect of tax sanctions is large enough to describe the magnitude of the influence of tax authorities on taxpayer compliance. The greater the pressure from the tax authorities on taxpayers, the greater the individual's intention to comply with taxes. 
The interaction between taxpayer knowledge regarding recurring tax amnesty and tax sanctions on tax compliance has been successfully demonstrated in this study. In the condition of taxpayers who do not know there is a recurring tax amnesty, and receive high tax sanctions, it will result in the highest taxpayer compliance. This is in line with the argument above which explains that if the taxpayer anticipates further tax amnesty (in this case it means that the taxpayer is aware of the tax amnesty), they can reduce their tax compliance, in other words if the taxpayer does not know about the recurring tax amnesty, they will will have a high level of compliance (Rechberger, et al. 2010) and the effect of tax sanctions can also affect taxpayers to comply with the tax system Hidayat and Nugroho (2010).

\section{CONCLUSION}

The conclusion in this study is that the knowledge of taxpayers on the application of repeated tax amnesty can affect taxpayer compliance. If the taxpayer is not aware of the repetition of the tax amnesty, it will encourage taxpayer compliance. The effect of tax sanctions on taxpayers also plays a role in determining compliance. Taxpayers who receive high tax sanctions will show higher compliance than those who receive low tax sanctions. In addition, there is an interaction between knowledge of recurring tax amnesty and tax sanctions in the study, both of which can jointly affect taxpayer compliance.

This research contributes to the development of research related to taxpayer compliance. The results of this study can be useful for the government to consider whether there is a need for a repeated tax amnesty if it is seen from the effect of a repeated tax amnesty that can reduce the level of compliance, and the government can consider a psychological approach to taxpayers rather than giving a warning in the form of sanctions and fines in its efforts to improve taxpayer compliance. The results of the study can help the government to pay more attention to the influence of social norms in increasing tax compliance. Individuals who are in confusing conditions such as repeated tax amnesty issues will look at the perceptions of other individuals in determining their actions. These results imply that the government in order to improve tax compliance can take action in the form of campaigns to community groups to be more obedient in carrying out tax obligations, ensuring that the public considers the tax system fair and utilized for the prosperity of the people. Individuals who are in confusing conditions such as repeated tax amnesty issues will look at the perceptions of other individuals in determining their actions.

The limitation of this study is that the pilot test was carried out once, but every important sentence in the simulation was given in bold, thus creating a bias. The use of students as professional translators can also be a limitation because the use of students may produce different results from the use of participants who are actually taxpayers

\section{Acknowledgement: None}

Conflict of Interest: None

\section{Source of Funding: None}

\section{REFERENCES}

1. Alm, James. "Tax Compliance and Administration." Discussion Papers in Economics, March 1998.

2. Alm, J., McKee, M., and Beck, W. 1990. Amazing Grace: Tax Amnesties and Compliance. National Tax Journal, 43(1), 23-37.

3. Ahmed, Sams Uddin. "Improving Compliance of Income Tax in Developing Countries: Bangladesh Perspective." 2016.

4. Ali, MM, Cecil, HW, and Knoblett, JA 2001. The Effects of Tax Rates and Enforcement Policies on Taxpayer Compliance: A Study of Self-Employed Taxpayers. Antlantic Economic Journal 29(2), 186-202. 
5. Allingham, MG, and Sandmo, A. 1972. Income Tax Evasion: A Theoretical Analysis. Journal of Public Economics, 1, 323-338

6. Ardiyanti, NPM, \& Supadmi, NL (2020). Effect of Tax Knowledge, Tax Socialization, and Application of Mobile SAMSAT Services on Taxpayer Compliance. E-Journal of Accounting, 30 (8), 1915-1926.

7. Cahyonowati, N., Ratmono, D., and Faisal. 2012. The Role of Ethics, Audits, and Tax Penalties to Improve Individual Taxpayer Compliance. Indonesian Journal of Accounting and Finance, 9(2), 136-153

8. Gerger, GC (2012). Tax Amnesty and Tax Compliance in Turkey. International Journal of Multidisciplinary Thought, 2(3), 107-113.

9. Hantoyo, SS, Kertahadi, and Handayani, SR 2016. The Effect of Tax Avoidance and Tax Sanctions on Taxpayer Compliance (Study on Taxpayers at the Tegal Pratama Tax Service Office). Journal of Taxation, 9(1).

10. Herman, LA, Dewi, AS, \& Dewi, MK (2019). Perceived Taxpayer Compliance Behavior Through Factors of Deterrence, Justice and Social Norms. Benefita Journal, 4(1), 146-161.

11. Holler, M., E. Hoezl, E, Kirchler and S. Leder. 2008. Framing of Information on the Use of Public Finances, Regulatory Fit of Recipients and Tax Compliance. Journal of Economic Psychology, 29, 579611

12. Hutagaol, J., Winarko, WW, and Pradipta, A. 2007. Strategies to Improve Taxpayer Compliance. Accountability, 6(2), 186193.

13. Hanno, DM and GR Violette. (1996). An Analysis of Moral and social Influences on Tax Payer Behavior. Behavioral Research in Accounting. 8 (Supplements)

14. Ibrahim, MA, Myrna, R., Irawati, I., \& Kristiadi, JB (2017). A systematic literature review on tax amnesty in 9 Asian countries. International Journal of Economics and Financial Issues, 7(3), 220-225

15. Kartini, U. (2018). The Effect of Tax Amnesty and Tax Sanctions on the
Compliance of Individual Taxpayers at the Pratama Tax Office, Purworejo Regency in 2016. The definition of taxation. Yogyakarta State University. (Thesis).

16. Lederman, L. 2003. The Interplay Between Norms and Enforcement In Tax Compliance. Ohio State Law Journal, 64(6), 1453-1514.

17. Lopez-Laborda, J., \& Fernando, R. (2003). Tax Amnesty and Income Tax Compliance: The Case of Spain. Fiscal Studies, 24(1), 73-96. doi:http://dx.doi.org/10.1111/j.14755890.2003.tb00077.x

18. Mardiasmo. (2016). Taxation Revised Edition 2016. Yogyakarta: Publisher Andi 19. Nurmantu, S. (2003). Introduction to Taxation. Jakarta: Granite

20. Puspareni, KD, Purnamawati, IGA, \& Wahyuni, MA (2017). The Effect of Tax Amnesty, Economic Growth, Taxpayer Compliance, and Institutional Transformation of the Directorate General of Taxes on Tax Revenue for the 2015 Fiscal Year at the Singaraja Pratama Tax Service Office. JIMAT (Accounting Student Scientific Journal) Undiksha, 7(1)

21. Ratmono \& Faisal. (2014). Voluntary Tax Compliance Model, Role of Fines, Procedural Fairness and Trust in Tax Authorities. Indonesian Journal of Accounting and Auditing, 2014

22. Rechberger, Silvia, Martina Hartner, Erich Kirchler, and Franziska Hämmerle. "Tax amnesties, justice perceptions, and filing behavior: a simulation study." Law Policy, 2010

23. Pranata, PA, and Setiawan, PE 2015. The Effect of Tax Sanctions, Service Quality and Moral Obligations on Taxpayer Compliance. Udayana University Accounting E-Journal, 10(2), 456-473.

24. Riasning, Ni Putu; Amlayasa, AA Good; Datrini, Luh Kade, (2020), Analysis of MSME Taxpayer Compliance In Badung, Bali-Indonesia, International Journal of Economics, Commerce and Management, United Kingdom, VIII-96-109

25. Supraja, G. (2020). The Effect of the Tax Amnesty Program on the Effectiveness of 
Ni Putu Riasning et.al. The effect of repeat tax amnesty and tax penalty policy on taxpayer compliance (an experimental study)

Tax Revenue in Indonesia. JOURNAL OF TAXATION, 1(2), 144-151.

26. Sari, VAP, \& Fidiana, F. (2017). The effect of tax amnesty, tax knowledge, and tax service services on taxpayer compliance. Journal of Accounting Science and Research (JIRA), 6(2).

27. Sholih, MW, Chariri, A., \& Ubaidillah, M. (2020). Religiosity, Procedural Fairness, Trust in Tax Authorities, and Voluntary Tax Compliance. Jaka (Journal of Accounting, Finance, and Auditing), 1(2).

28. Saleh, R. (2004). Empirical Study on Timeliness of Financial Reporting of Manufacturing Companies on the Jakarta Stock Exchange (Doctoral dissertation,
Postgraduate Program at Diponegoro University).

29. Zuraeva, M., \& Rulandari, N. (2020). Analysis of the Quality of Tax Services in the Context of Improving Taxpayer Compliance (Case Study of Kpp Pratama Jakarta Monday 2018). Journal of Vocational Taxes (JUPASI), 2(1), 37-44.

How to cite this article: Ni Putu Riasning, Anak Agung Bagus Amlayasa, Luh Kade Datrini. The effect of repeat tax amnesty and tax penalty policy on taxpayer compliance (an experimental study). International Journal of Research and Review. 2021; 8(10): 105-116. DOI: https://doi.org/10.52403/ijrr.20211015 